\title{
The Spirituality of Rural Muslim Communities through Jam'iyyah Nahdlatul Ulama Routine Activities
}

\author{
Hendri Hermawan Adinugraha ${ }^{1 *}$, Maaz Ud Din ${ }^{2}$, Ali Muhtarom ${ }^{3}$ \\ ${ }^{1}$ State Islamic Institute of Pekalongan, Indonesia (hendri.hermawan@iainpekalongan.ac.id) \\ 2University of Swabi-KP, Pakistan (maazyousafzai12@gmail.com) \\ ${ }^{3}$ State Islamic Institute of Pekalongan, Indonesia (ali.muhtarom@iainpekalongan.ac.id)
}

\begin{abstract}
The purpose of this research is to describe the spirituality of rural Muslim communities through the routine activities of Jam'iyyah Nahdlatul Ulama from Ngemplak Simongan NU Sub-District. This research is a field research (qualitative) which elaborated phenomenology approach that uses observation, interviews, and documentation as a method of collecting data, which is also equipped with a library research. The research shows that the spirituality of the Muslim community and the Jam'iyyah NU, Ngemplak Simongan Village is also still very much carrying the spirit of local wisdom based on Islamic values to this day. They also still carry out Javanese religious rituals, such as routine recitation activities, tahlil, yasinan, diba', istighāstah, manāqib, and ziyārah Walisongo, because they believe that basically all of these rituals are part of Islamic teachings and originated from Islamic teachings. Jam'iyyah NU Ngemplak Simongan can also be categorized as "Moderate Muslim" because they still uphold the values of locality in religion. Based on the results, it shows that Jam'iyyah NU, Ngemplak can be used as a miniature of NU moderation in suburban villages of Semarang City. Jam'iyyah NU, Ngemplak, which in fact is a sub-district in the metropolitan city of Semarang, Central Java, they often and routinely carry out Ahlussunnah wal Jama'ah An-Nahdliyyah (Aswaja NU) activities to maintain the spiritual spirit of rural Muslim communities.
\end{abstract}

Keywords: Spirituality, NU, Moderate, Aswaja.

\begin{abstract}
ABSTRAK
Tujuan penelitian ini adalah untuk mendeskripsikan spiritualitas masyarakat Muslim pedesaan melalui kegiatan rutin Jam'iyyah Nahdlatul Ulama dari Kecamatan Ngemplak Simongan NU. Penelitian ini merupakan penelitian lapangan (kualitatif) dengan pendekatan fenomenologi yang menggunakan observasi, wawancara, dan dokumentasi sebagai metode pengumpulan datanya, yang juga dilengkapi dengan studi pustaka. Penelitian ini menunjukan hasil bahwa spiritualitas masyarakat Muslim dan Jam'iyyah NU Kelurahan Ngemplak Simongan juga masih sangat mengusung semangat kearifan lokal berdasarkan
\end{abstract}


nilai-nilai Islam hingga saat ini. Mereka juga masih menjalankan ritual keagamaan Jawa, seperti kegiatan rutin pengajian, tahlil, yasinan, diba', istighāstah, manāqib, dan ziyārah Walisongo, karena mereka berkeyakinan bahwa pada dasarnya semua ritual tersebut merupakan bagian dari ajaran Islam serta bersumber dari ajaran Islam. Jam'iyyah NU Kelurahan Ngemplak Simongan juga dapat dikatagorikan sebagai "Muslim Moderat" karena mereka masih menjunjung tinggi nilai-nilai lokalitas dalam beragama. Hasil penelitian ini menunjukkan bahwa Jam'iyyah NU Kelurahan Ngemplak Simongan bisa dijadikan miniature kemoderatan NU di desa pinggiran Kota Semarang. Jam'iyyah NU Kelurahan Ngemplak Simongan, yang notabene sebagai Kelurahan yang ada di Kota metropolitan Semarang Jawa Tengah, sering dan rutin melakukan kegiatan Ahlussunnah wal Jama'ah An-Nahdliyyah (Aswaja NU) untuk menjaga jiwa spiritualitas masyarakat Muslim pedesaan.

Kata kunci: Spiritualitas, NU, moderat, dan Aswaja.

\section{INTRODUCTION}

Islam is a universal religion rahmatan lil 'alamin. This means that the mission and teachings of Islam are not only aimed at one group or country, but all mankind, even the universe. However, the meaning of the universality of Islam among Muslims is not uniform. There is a group that defines that the teachings of Islam brought by the Prophet Muhammad, which in fact have an Arabic culture, are final, so they must be followed as they are. There are also groups that interpret the universality of Islamic teachings as being not limited to time and place, so that they can enter any culture. The presence of the Nahdlatul Ulama (NU) emerged as a result of the "failure" of the first group to present an unfriendly face of Islam and tended to impose on other cultures, even using violence in preaching Islam (substantive). Likewise, the second group that is considered distorting Islamic teachings (normative) (Luthfi, 2016).

Nahdlatul Ulama (NU) was founded on January 31, 1926 to coincide with Rajab $161334 \mathrm{H}$. in Surabaya by K.H. Hasyim Asy'ari along with traditional ulama figures and businessmen in East Java. The establishment of NU began with the birth of Nahdlatuttujjar (1918) which emerged as an institution for a rural economic movement, followed by the emergence of Taswirul Afkar (1922) as a scientific and cultural movement, and Nahdatul Watan (1924) as a political movement in the form of education. There are three important pillars for NU, namely: (1) Social economic insight, (2) Scientific, Socio-cultural insight, and (3) National insight. After NU was officially established as jam'iyah in 1926, there have been many madrasas standing beside the Islamic boarding schools that have long existed and taken root in Indonesia. Seeing the reality at that time, the Second Congress of 1927 discussed the problem of improving teaching methods in Islamic boarding schools and madrasas. Furthermore, at the Third Congress in 1928 in Surabaya, the development and expansion of Islamic boarding schools and madrassas were discussed (Rahim, n.d.). Until now, NU still exists both at the national and international levels. Spirit was born as a jam'iyyah based on the symbol and power of the ulama or Kiai (Mahatma, 2017).

One of the permanent programs of Nahdatul Ulama is matters of scientific, social and cultural insight, which is named with the spiritual term jam'iyah NU through the jargon Ahlussunnah wal 
Jama'ah An-Nahdliyyah (Aswaja NU). All of Nahdatul Ulama's work programs are not merely an attempt to achieve a new goal, but first of all it is a manifestation of the implementation of Islamic religious teachings. Therefore $\mathrm{KH}$. A. Hasyim Muzadi once said that "every citizen and board of Nahdlatul Ulama (NU) should not only be proud of the large number of members, but what they are actually proud of is the content of their heads". Therefore, all NU residents (Nahdliyin) wherever they are, both in villages / villages and in the city should always struggle fi sabilillah to revive and support NU. There is no one deed that is wasted if our intention as Nahdliyin just for Allah is to benefit others.

The teachings of Ahlussunnah wal Jama'ah An-Nahdliyyah (Aswaja NU) are characterized by tawāsuth, ta'ādul, and tawāzun. These three characteristics are combined into the term "wasathiyah". One of the characters of this wasathiyah Islam is embodied in the QS. Al-Baqarah: 143, which means: "And thus (also) we make you (Muslims), the mediator (fair and elect), so that you become witnesses to all mankind and for the Prophet (Muhammad SAW) to be a witness against you".

The word وَسَطً in the word of Allah in the perspective of the Prophet Muhammad SAW is

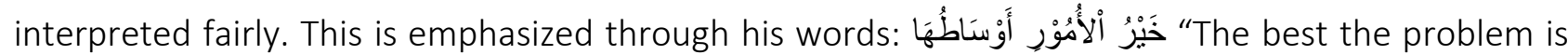

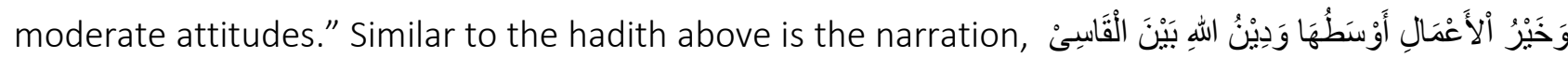
A و أنغَالِّن Wasathiyyah which is often translated as "moderation" has several meanings as follows: First, justice between two zealots (عدل بين ظلمين) or the truth between two falsehoods (حق بين باطلين). Second, the integration of two different or opposing things (eg wasathiyyah between spiritual and physical, between nushûs and maqāṣīd, between `aql and naql, etc.). Third, realistic (wāqi'iyyah). Islam is a religion that is realistic and always contextual.

The character of wasathiyyah in Aswaja NU always bases Islamic teachings on the Al-Qur'an and As-sunnah as the main source (Wahyudin, 2017), and also to secondary sources that refer to AlQur'an and As-sunnah such as doing ijtihad through ijma 'and qiyās; acknowledging the virtue and justice of the companions of the Prophet; admits there is no Prophet after Prophet Muhammad as a ma'shum person; Respect for differences of opinion in masāil furu'iyyah-ijtihadiyah is a must because it is one of the nature of humanity; avoid things that give rise to hostility; maintaining ukhuwwah imāniyyah-islāmiyyah among the Muslims and ukhuwwah wathaniyyah against adherents of other religions, as well as maintaining ukhuwwah nahdliyyah towards all NU citizens; and maintaining a balance (tawāzun) between aspects of the afterlife and in life.

Life in the village is always closely related to cultural and religious elements (Ryan, 2020). The religious ritual system in the village cannot be completely separated from the traditions and culture of NU. Sociologically, the people of Ngemplak Simongan Village are Nahdliyin people although organizationally it is not included in the routine program of the NU Subdistrict management, the fact is that activities that reflect NU culture have been running for quite a long time and are good in the Nahdliyin community of Ngemplak Simongan Village. NU-ness traditions that are still attached to the village community are such as the routine activities of recitation, tahlil, yasinan, diba ', istighāstah, manāqib, ziyārah Walisongo which have indeed been running and have become a good culture in the people of Ngemplak Simongan Village. 
Jam'iyyah NU in villages should have the competence to carry out participatory social activity processes. So that they are able to mobilize NU institutions to take an important role at the village level. Of course, not only the formal institutional structure, NU cultural spaces in the village are also designed to have sensitivity in responding to the social and economic problems of the community in the village. An example of a social problem that often occurs in Muslim communities in Indonesia is the difference in worship practices carried out by the NU and Muhammadiyah organizations (Siregar \& Suhendra, 2020). Rites of worship or rituals are the manifest function of religion, namely, which symbolizes doctrine and reminds humans of that doctrine. This incomprehensible difference begins with blasphemy that creates hatred and ethnocentrism and leads to stereotypes (Rohmah, 2016). The two religious organizations have been known as representatives of moderate Islam in Indonesia (Hilmy, 2012).

$\mathrm{NU}$ as the representative of the village people in Ngemplak Simongan has been running quite well, for example, the social and economic activities of the NU branch of Ngemplak Simongan Village have been able to optimize LAZ and assist the construction of the Al-Hikmah Nurul IImi Islamic Boarding School (AHNIS) in Gunungpati. As a part of NU, jam'iyyah nahdliyyin should continue to struggle to revive and support NU even though it starts from a small scope (village) for the benefit and solemnity of the ummah. In essence, NU is a religious organization that is oriented towards the interests and benefits of the people (Febrina et al., 2016). Therefore, this research is very relevant to be studied to describe the routine activities of the Jam'iyyah Nahdlatul Ulama which is the spiritual soul of the rural Muslim community. This research was conducted in the NU branch of the Ngemplak Simongan sub-district which is actually a sub-district in the metropolitan city of Semarang, Central Java.

\section{METHODS}

This research is a field or research qualitative with phenomenology approach that uses observation, interviews, and documentation (triangulation) as a method of collecting data, this research is also equipped a literature or library research sourced from authoritative journals, books, and documents that are still relevant to the study of the spirituality of rural Muslim communities through the routine activities of Jam'iyyah Nahdlatul Ulama. Informants this research are society, member and organization committee of Ngemplak Simongan Jam'iyyah Nahdlatul Ulama. Place of research is Ngemplak Simongan. Time of research in January to April 2021.

\section{RESULTS AND DISCUSSION}

\subsection{Realization of NU Subdistrict Activities in Ngemplak Simongan}

As the largest Islamic organization in Indonesia, Nahdatul Ulama (NU) certainly has enormous urgency in building governance in Indonesia. NU has contributed many roles and services to the Indonesian state from the social, political, educational and economic aspects. For example the results of Aliman Saragih's research which concluded that one of the factors that led to Indonesia's independence was the contribution of Al-Jam'iyatul Washliyah which was part of the NU environment (Saragih, 2016).

Based on the social side of the role of $\mathrm{NU}$, it can be seen that the efforts to reaffirm all religious and social traditions that have actually been institutionalized in an established network of 
leadership structures and patterns. From a political point of view, NU has become a milestone in the forefront of protecting the integrity of the Republic of Indonesia from dangerous understandings (L. Man, 2018). Sociologically, the people of Ngemplak Simongan Village are Nahdliyin people, although organizationally it is not included in the routine program of the Ngemplak Simongan Subdistrict's NU management, the fact is that activities that reflect NU culture have run quite well in the Nahdliyin community of Ngemplak Simongan Village. Some of the organizational managerial activities as well as the Aswaja NU habituation to maintain the spirituality of the rural Muslim community that have been carried out (have been carried out) by the administrators of NU Ngemplak Simongan Branch are as follows:

\section{Field of Organization}

Religious organizations are a form of society formed on the basis of equality in both religious activities and professions (Dimas Prayoga, 2017). In the organizational field, the management of the NU Subdistrict of Ngemplak Simongan Subdistrict has not been able to run optimally, in the 20192020 period there was a lack of management activities due to the Covid-19 outbreak, routine activities had not been programmed and organized systematically. Even so, the administrators of the NU branch of the Ngemplak Simongan sub-district are individually quite active in activities in the community such as routine recitation activities, tahlil, yasinan, diba ', istighosah, manaqib and others that are already running in the community. This is in accordance with Mahrus As'ad's (2014) research which states that before the reformation, the concept of "Islamic education" in Indonesia refers to the learning activity of religious sciences (knowledge), which in terms of systems and institutions is simple, called "pengajian", both Al-Quran recitation and book recitation.

In the field of organization, the management of the Ngemplak Simongan branch has implemented the KARTANU (NU Membership Card) program, which was held on April 17, 2019 at the Ngemplak Simongan Village meeting hall, which recorded around 870 residents who participated in the printing of KARTANU. With KARTANU, it is hoped that the organization's human resources can be recorded properly. In the organizational field, the administrators of the NU branch of the Ngemplak Simongan sub-district in 2019 have formed the Ngemplak Simongan Branch of the Amil Zakat Institute, and the NU Peduli Coin Team, which will provide detailed reports on the Social and Economic fields. In the future, the management of the new NU Ngemplak Simongan branch is expected to be able to run the organization by planning and running the right work program, so that not only a strong NU culture, but the Ngemplak Simongan NU branch can also be strong and develop in the field of organizational management.

The field of Da'wah

Currently the digital da'wah of Nahdlatul Ulama is indeed used to provide understanding to the public to behave in accordance with the values contained in Aswaja NU (Hakim and Aziz, 2020). NU and Muhammadiyah as the largest moderate-leaning Islamic organizations in Indonesia need to spread their da'wah wings through digital technology tools. This needs to be seriously pursued considering that the movement of messages of radicalism in religious clothing has also flooded the channels of the digital world so far. So far they have taken advantage of the existence of technology to disseminate the notion of terrorism which they call "jihad". If this is allowed in the sense of not 
making the digital world a da'wah field like the real world, then it is not impossible that extremist understanding will win public opinion and sympathy in cyberspace (Fithriyyah \& Umam, 2018).

The administrators of the NU Subdistrict of Ngemplak Simongan Subdistrict have not been able to carry out the da'wah field program optimally, even though there are only a few routine activities that have been programmed and have been carried out, including: a. Ziaroh Ancestral Graves Ziaroh ancestral graves are carried out routinely before the beginning of the Hijri year, followed by all nahdliyin residents in Ngemplak Simongan Village. It was recorded that approximately 150 residents ( 3 buses) attended this routine. The places that are visited are the graves of ancestors in Central Java, East Java, Yogyakarta, West Java and Banten. b. Lail prayers and dzikir Kegaitan Lail prayers and dzikir are routinely carried out on odd nights in the month of Ramadan, namely the night of 21, 23, 25, 27, 29 Ramadan starting at 01.30 WIB (early morning). This activity was held at mosques in the Ngemplak Simongan Village. However, those that have carried out this activity are only the AlHikmah Ngemplak Simongan Mosque and the Al-Amin Brimob Mosque. The series of activities for the Lail prayer include: 1. Repentance prayer 2. Intentional prayer 3. Lailatul qodar prayer. Then proceed with the recitation of zikr: 1. Istighfar 70 times 2. Surah fatihah 3 times 3 . Sholawat 77 times 4. Hasbunallah 77 times 5. Prayer lailatul qodar 11 times 6. Thoyyibah sentence 41 times 7. Prayer c. Tomb Pilgrimage and Interactive Dialogue Routine activities of Cemetery pilgrimage and interactive dialogue are monthly routine activities of the Ngemplak Simongan branch of the NU management, this activity is carried out at the end of each month where the places are rotated to the tombs in Ngemplak Simongan Village. The activities carried out in this routine are tahlil which is continued with interactive dialogue to solve the problems of the nahdliyin residents, the speakers for this interactive dialogue are taken from the administrators of the Ngemplak Simongan NU branch, Modin Ngemplak Simongan Village, Head of the Village and the Ngemplak Simongan apparatus, Mosque management (ta'mir) Ngemplak Simongan. Since the implementation of this routine activity, 17 problems in the fields of Religion, Social/Death/Bride, NUs, State, and faith have been resolved than can add new knowledge to Nahdliyin residents in Ngemplak Simongan Village.

Based on some of the explanations above, a common thread can be drawn that the teachings of Ahlusunnah wal Jama'ah (Aswaja) greatly influenced the people of Ngemplak Simongan Village because the style and teaching methods were easily accepted by all Muslims so that their thoughts were like; about the nature of God, human actions, acts of God, anthropormosism, seeing God, the words of Allah, and the position of reason are easily accepted by the community. In addition, the customs of the Aswaja people, one of which is the tradition of tahlil and yasinan every Friday night, with that there will be a positive impact, namely the creation of a very high sense of solidarity (Surur \& Munir, 2018).

$\mathrm{NU}$ as the representative of the village people in Ngemplak Simongan has been running quite well, for example, the social and economic activities of the NU branch of Ngemplak Simongan Village have been able to optimize LAZ and assist the construction of the Al-Hikmah Nurul IImi Islamic Boarding School (AHNIS) in Gunungpati. Because basically, pesantren are the oldest educational institutions in Indonesia. The pesantren was originally developed by kiai on the island of Java and affiliated with Nahdlatul Ulama (Salamuddin, 2019). This was also confirmed by the Mubin (2020) who stated that the NU organizational tree was very lush 
by educational institutions such as pesantren, majelis taklim, diniyyah, madrasas or schools and universities.

\section{Social and Economic Sector}

Social and economic activities of the Ngemplak Simongan Subdistrict's NU Subdistrict Management are not yet visible in the field, because technically, activities in this field have been mostly handled by the Management of the Muslimat and Ansor Subdistricts of Ngemplak Simongan Village and also groups that are competent in their fields. . In the social and economic field, the administrators of the NU Subdistrict of Ngemplak Simongan Sub-district are only able to implement: 1) The Ngemplak Simongan Branch of the Amil Zakat Institute of NU-The NU Ngemplak Simongan branch of the Amil Zakat Institute has carried out the collection and distribution of zakat fitrah on the night of 1 Syawal $1441 \mathrm{H}$ which is centralized in the Jami' Al-Hikmah Ngemplak Simongan Mosque. The details of the acquisition of Zakat Fitrah NU by Ngemplak Simongan for Faqir, Poor, Amil, Muallaf, Riqob, Ghorim, Sabilillah, and Ibn Sabil are as follows: Rice $2500 \mathrm{Kg}$; 2) Koin NU Peduli - The activity of the NU Peduli Coin only started on July 222017 and was confirmed on August 25302019 with the acquisition of IDR 6,603,400 (Six Million Six Hundred Three Thousand Four Hundred Rupiah). In the future, we hope that the social and economic sector is a program that is very much needed by the community, so that the new management can continue the existing program more optimally and make new programs that are more innovative and creative so that the residents of Nadhliyin Ngemplak Simongan can really feel the benefits of the program; 3 ) Regeneration field - In the field of regeneration, the administrators of the NU Subdistrict of Ngemplak Simongan Sub-district have not been able to make and implement programs optimally. The administrators of the Ngemplak Simongan Subdistrict NU were only able to participate in dispatching 4 NU PKP participants organized by MWC NU West Semarang District as many as 4 people. In the future, we hope that the field of regeneration is quite an important field, so that the new Ngemplak Simongan sub-district administrators must have a regeneration program so that in the long run new, more professional and competent cadres can be born.

\subsection{Moderation of Islam at Jam'iyyah Nahdlatul Ulama Branch of Ngemplak Simongan}

Religious moderation in overcoming the problem of radicalism. For this reason, Islamic moderation deserves to be positioned as the main stream of Islamic education in Indonesia. This mainstream needs to be developed into a model of world Islamic moderation education. "The Ministry of Religion has made Islamic moderation and Islamic learning rahmatan lil Alamin the main streams of Islamic education, both at the primary, secondary, and tertiary levels". The principle of moderation which is a perspective and ideology is a unifying tool in diversity, so that its absolute existence in a multicultural country like Indonesia (Fuad, 2020).

Islam in Indonesia is still considered moderate Islam. Nahdlatul Ulama can be seen as the guardian of Islamic moderatism in Indonesia. So far, Nahdlatul Ulama can serve as a stepping stone to build a more responsible formulation of Indonesian Islam in the future. The findings of this study present the routine activities of Jam'iyyah Nahdlatul Ulama which are the spiritual soul of rural Muslim communities to ward off radicalism in sub-districts located on the outskirts of Semarang City, Central Java. 
However, along with the development of contemporary Islamic thought and movements, a new reality has emerged which shows a shift. In the body of NU, for example, even though NU is typologically thick with traditional Islamic styles, in current developments, the mention of Nahdlatul Ulama (NU) as a representation of traditionalist Islam is not fully relevant, because on many occasions there have been many great NU thinkers and figures from in terms of thought and ideas are progressive and modern. In fact, several central figures of NU, namely Gus Dur, have become one of the icons of $\mathrm{NU}$ whose thoughts are considered to have strong relevance to the modern spirit, because of their very moderate attitude and stance.

In Indonesia, both NU and Muhammadiyah, apart from being known as large mass organizations, are also known as Islamic organizations that represent Islamic moderatism in Indonesia. In general, the value of both moderatism is clearly reflected in the acceptance of the Indonesian people, so that until now these two mass organizations are still strong in maintaining harmony with the activities of community life. Muhammadiyah moderation has the advantage of accommodating the culture of a cosmopolitan society, therefore they are more active in the city community level. On the other hand, NU's moderate value is reflected in its acceptance of local traditions, thus making its existence easily accepted by the community. Therefore, those who became Jam'iyyah NU were dominated by people who came from rural areas (Fithriyyah \& Umam, 2018). This research also shows the same results as the description above, the people of Ngemplak Simongan Village become Jam'iyyah NU who come from rural areas on the outskirts of Semarang City.

With regard to NU, quantitatively, it can be ascertained that the existence of $\mathrm{NU}$ is a characteristic representation of the majority of Islam in Indonesia. This is based on the fact that the majority of Indonesians are registered as members of NU. The fact that NU is the majority Islamic mass organization, to certain limits, has a significant influence on the face of Indonesian Islam, which on many occasions is very thick with the Islamic aroma of NU. Namely, one Islamic dimension that is thick with traditions and values of locality. This is understandable, considering that the Islamic typology promoted by NU itself has a spirit of locality that is based on the values of local wisdom. Especially those dealing with culture, traditions and customs (Fithriyyah \& Umam, 2018). This has also been proven to have happened in Ngemplak Simongan.

As for the portrait of moderate Islam in Indonesia, whether we realize it or not, the discussion of modern Islam in Indonesia is a religious theme that is not only important but also interesting. It is said to be interesting because as we all know, Indonesia is a form of a country that has multiple geographic characteristics. Consisting of hundreds, even thousands of islands. Each island is filled with different tribes and ethnicities. Each of them has a cultural background, customs, traditions, and even systems and forms of belief (religion) differ from one another. The fact of all these differences is clear evidence of how Indonesia is a plural country whose existence must be maintained, cared for, managed, and even must be balanced by a building system of regulations that can embrace all of them. In this regard, discussing moderate Islam has the same position as discussing the reality of a pluralistic and diverse Indonesia. The prominence and diversity of Indonesia has one strength and wealth of Indonesia that is not only unique, unique, but also interesting in the eyes of other countries. (Fithriyyah \& Umam, 2018). 
At the same time, the discourse of moderate Islam in Indonesia is considered important because in reality, there are currently many attitudes, behaviors and actions of religious sentiments that tend to be anarchic, violent, and contain violence. Symptoms in this direction are evident in the current reality (understand / group) of Indonesian religions. There have been many incidents of friction, disputes, and even acts of persecution between one another. The culmination of all this is the escalation of clashes and conflicts between (understand) religions, which are obviously a major threat. Not only for the stability of the nation and state, but also for the integrity of the Unitary State of the Republic of Indonesia (NKRI), as demonstrated by groups or religious understandings that flow with fundamentalism and extremism.

In Indonesia, the term moderate Islam has actually been rolling for a long time, the discussion about it has been raised on many occasions. In the political sector, especially at the beginning of Indonesia's democratic transition after the 1998 reformation, the term moderate Islam was echoed on a large scale. The aim was none other than to harmonize the relationship between democracy and Islam, which at that time sparked debate in many circles. Many groups think that democracy can be put together, because both are one universal view of life that offers a common vision and mission building.

Based on the historical facts of moderate Islam in Indonesia, by tolerating local traditions and accommodating then modifying them into Islamic teachings by always relying on the principles of Islamic teachings. The Islamic transmission pioneered by Walisonggo is a smart-brilliant struggle that is implemented in a simple way, namely showing new paths and alternatives that do not disturb local traditions and customs, and are easily captured by ordinary people because of their concrete and realistic approaches, and integrated with the life of the local community. . This model shows the uniqueness of Javanese Sufi which is able to absorb local and foreign cultural elements, but at the same time still stands firmly on Islamic principles.

Genealogically, moderate Islam has actually been introduced in practice. Especially through the Islamic values brought by Walisongo. Walisongo is a figure of a da'wah actor in the XV-XVI centuries who is known to have succeeded in integrating religious aspects with cultural products or traditions outside it. Integrate the habits of society that are transindent with something that is profane. Through their da'wah model that carries cultural principles, Walisongo has succeeded in introducing the face of the mercy of Islam in an elegant way. This method has significantly succeeded in influencing many societies. Based on historical facts, that by tolerating local traditions and modifying them into Islamic teachings and still relying on Islamic principles. In fact, Islam was embraced by the aristocracy and the majority of Javanese people on the north coast. The presence of the face of Indonesian Islam that carries the spirit of local wisdom is the original character of the moderate form of archipelago (Indonesian) philosophy (Fithriyyah \& Umam, 2018). It is not surprising that the findings of this study indicate that the spirit of spirituality of the Muslim community in Ngemplak Simongan Village is still very much carrying the spirit of local wisdom to this day.

The concept of moderation in Nusantara Islam, among others, was initiated by KH. Said Aqil Siradj, namely Islam Nusantara is not a new teaching or sect in Islam so there is no need to worry. According to him, this concept is the view of Indonesian Muslims which is inherent in the culture of the archipelago. KH. Said Aqil Siradj explained that Muslims living in Indonesia are very close to the 
culture in which they live and this is the basis for the emergence of the concept of Nusantara Islam. The view above indicates the understanding of Nusantara Islam, namely the understanding of Islam of Muslims in Indonesia which cannot be separated from the context of the social, cultural and traditional backgrounds of the Indonesian people. Islam that lives in synergy with the cultural reality of the people of the archipelago. This does not mean that Nusantara Islam is a sect or sect or even a new school of Islam, but rather an aspect of Islamic da'wah methodology developed in the context of Indonesian society. In addition, Islam Nusantara sociologically, is the result of the interaction process of Islamic teachings brought by Walisongo and archipelago ulama which Islamic scholarship continues to the scholars up to the Prophet Muhammad SAW. So it does not contradict the basic Islamic understanding (ushul) conveyed and agreed upon by the ulama Ahlussunnah wal Jama'ah (Mussardo, 2019).

A number of Muslim circles emphasize that Islam regarding the Islam of this archipelago, if examined in depth and from a broad Islamic perspective, it is found that almost all teachings, traditions, and spiritual emphases that have been developing in Javanese society, basically come from Islamic teachings in the Middle East. Javanese religious ceremonies, such as grebeg, selametan, kalimasodo, are part of Islamic teachings. In addition, the Kawula Gusti Martabat Tujuh doctrine and wayang tradition which are known and preserved in Javanese society can be traced to their origins from the Islamic Sufism tradition (Fithriyyah \& Umam, 2018). The results of this study indicate that the Muslim community of Jam'iyyah NU Ngemplak Simongan still performs Javanese religious rituals, such as grebeg, selametan, tahlilan or yainan, because they believe that basically all of these rituals are part of Islamic teachings and originate from Islamic teachings.

In the context of contemporary Indonesian Islamic dynamics, the term moderate Islam has been based on two major Islamic organizations, namely NU and Muhammadiyah. Although they exist in different poles, both are bound by the same viewpoint to carry out the function of the blessing of Islam, namely to present a religious form that is in accordance with the reality of the Indonesian nation. A nation that is formed on a typology of a pluralistic, diverse, plural and diverse society. In NU, moderate Islamic attitudes are reflected in their commitment to present an Islamic characteristic that can be affectionate with local values (Fithriyyah \& Umam, 2018). In accordance with this description, the Jam'iyyah NU Ngemplak Simongan can also be categorized as "Moderate Muslim" because they still uphold the values of locality in religion.

Moderate claims to the existence of NU do not simply lie in their culturally biased Islamic spirit. More than that, there is the spirit of their teachings which are contained in three principles, namely al-tawâssuth (in the middle), I'tidâl (upright, not leaning to the right or left), and al-tawâzun (balance, not heavy). Between the worldly and ukhrawi dimensions). Thus it is clearly stated in the Muqaddimah of Nahdlatul Ulama 2010 Articles of Association: "In order to create fair, peaceful and humane relations between nations that demand mutual understanding and mutual need, Nahdlatul Ulama is determined to develop ukhuwwah Islamiyah, ukhuwwah Wathaniyah, and ukhuwwah Insaniyah that carry national interests, and internationally by adhering to the principles of al-ikhlas (sincerity), al-is (justice), al-tawassut (moderation), altawazun (balance), and altasamuh (tolerance)".

Based on these ideologies, teachings, and moderate values, it is clear that the Jam'iyyah NU Ngemplak Simongan Village is a miniature of NU moderation in the suburban village of Semarang 
City. Both in religion, nation, social, and state, which are absolutely different from the radical-liberal Islamic movement which has a tendency to behave excessively. It is also different from the radicalfundamentalist movement of Islamism which is always oriented towards a rigid and normative meaning and understanding of Islam.

\subsection{Aswaja NU's Teachings: the Spirituality of Suburban Muslim Community Representation}

Radicalism or religious intolerance is a phenomenon that has become increasingly prevalent in Indonesia in recent years. This is marked by the birth of religious organizations that often use violent means in carrying out their missions. Radical Islamic organizations have various characteristics, variants and orientations. However, there are similarities among radical Islamic organizations, namely the use of violence.

The massive growth of the radical Islamic movement has received various responses from various parties. There are those who give a positive response by being supportive, some are giving a reactive-emotional response, some are giving a creative response, and some are responding anarchically. So far, the responses given have not been able to anticipate the growth rate of the radical Islamic movement. In fact, there is a tendency for an increase in the number of members in various radical Islamic organizations. The growing development of radical Islamic movements poses a separate threat to the Indonesian nation, which is rich in diversity. That is why various efforts must be made to prevent the development of radical Islam. The habituation of Aswaja NU's activities to maintain the spirituality of the rural Muslim community is a strategic enough medium to carry out the function of deradicalisation (Naim, 2015).

Radicalism can result in terrorism becoming an important problem for Muslims today. To overcome this, it is hoped that the involvement of various parties, especially the role of religious organizations (such as NU), is very likely to be an antidote to radical Islam, namely by instilling moderate Islam with the Aswaja concept (Prasetiawati, 2017). Because the existence of radical Islamic organizations is actually a threat to the future of Indonesian Islam. Indonesian Islam is an Islam known for its friendly, tolerant and humanist character. The dynamics and growth of Islam in Indonesia for hundreds of years show that a tolerant and peaceful Islam can live together with Indonesian society. Radical Islam is actually a characteristic of Islam that has no hope of life in the future. This is partly due to the denial by radical Islamic groups of the wisdom of Indonesian cultural values. Because they do not respect the values of Indonesian culture, radical Islam often uses methods that are contrary to the cultural reality that has been deeply rooted in society, especially Muslim communities in rural areas. For example, Jam'iyyah NU, Ngemplak Simongan sub-district, which in fact is a sub-district in the metropolitan city of Semarang, Central Java, they often and routinely carry out Ahlussunnah wal Jama'ah An-Nahdliyyah (Aswaja NU) activities to maintain the spiritual spirit of rural Muslim communities.

Substantially, in Islamic theology books, Aswaja is called a sect while in the books of the science of kalam it is called firqah; In NU's Articles of Association, Aswaja is referred to as understand; in another part, during this time Aswaja is still often understood as a school. According to Said Agil Siraj, Aswaja is actually not a mazhab, but only manhaj al-fikr or an understanding in which there are still many schools or schools of thought (Qomar, 2014). Therefore, Aswaja is not a new sect that emerged as a reaction from several schools that deviate from the true teachings of Islam, but Aswaja is pure Islam as taught by the Prophet Muhammad and his companions. Therefore, there is 
no one who is the founder of Aswaja's teachings, only scholars' who have reformulated the teachings of Islam after the birth of several religious beliefs and schools that tried to obscure the teachings of the Prophet Muhammad and his companions. Understanding Aswaja includes aspects of aqidah, Sharia and morals or tasawuf. In the field of aqidah or tauhid it follows the thoughts of Abu Hasan Al-Asy'ari and Al-Maturidi. In the issue of Sharia or Fiqh follow the four mdzhab namely Imam Syafi'i, Imam Hanafi, Imam Maliki and Imam Hanbali. In the field of Sufism, follow the opinions of Imam Al-Ghozali and Imam Al-Junaidi (Munawir, 2016). Basically moral problems in Indonesia actually culminate in knowledge, this is in our national education, slowly but surely, knowledge has been removed from real charity (Hidayah, 2015).

The majority of the people of Ngemplak Simongan are Muslim and claim to be followers of the NU organization and adhere to its teachings, namely Aswaja. In worship activities, they carry out activities in accordance with what Aswaja teaches, namely prioritizing the Sunnah of the Prophet. Not only in worship activities, but in carrying out daily activities, they also refer to what NU and Aswaja teach, including in choosing educational institutions (Yunus, 2019).

The Aswaja NU teachings that have been routinely carried out by Jam'iyyah NU, Ngemplak Simongan Village are quite strategic in carrying out the role of deradicalisation. Aswaja contains several substantial values, namely tawassut (moderate), tawazun (balanced), and tasamuh (tolerance). These values are important assets for building a less extreme understanding of Islam. Aswaja is significant to be carried out as a routine activity as an asset to guide daily religious life and to maintain the spiritual spirit of the Muslim community. This teaching for Muslim communities in rural areas can be very functional-applicable and provide active-creative responses in dealing with the increasingly complex realities of socio-religious life in daily religious life. Therefore, the internalization of Aswaja in daily religious life for Muslim communities in rural areas can be done through habituation of daily worship in accordance with Aswaja's teachings. Based on the results of observations and interviews, it was found that the research results showed that Jam'iyyah NU, Ngemplak Simongan Village was still consistent in maintaining its spiritual spirit through habituation of daily worship in accordance with Aswaja's teachings.

\section{CONCLUSION}

Sociologically, the people of Ngemplak Simongan Village are Nahdliyin people, although organizationally not all of them are included in the management of the NU Subdistrict, this can be seen from their activities that reflect NU culture. NU-ness traditions that are still inherent in the Ngemplak Simongan Village are such as the routine activities of recitation, tahlil, yasinan, diba ', istighāstah, manāqib, ziyārah Walisongo which have actually been running well in the community of Ngemplak Simongan Village. NU as a representative of the village people in Ngemplak Simongan has run quite well, several organizational managerial activities and Aswaja NU habituation to maintain the spirituality of the rural Muslim community that have been carried out by the management and Jam'iyyah NU Ranting Ngemplak Simongan are in the field of organization, the field of da'wah, and social and economic fields.

This research also shows the results that the spirituality of the Muslim community and Jam'iyyah NU, Ngemplak Simongan Village has the spirit of local wisdom that upholds Islamic values. They also still carry out Javanese religious rituals, because they believe that basically all of 
these rituals are part of Islamic teachings and originate from Islamic teachings. Jam'iyyah NU Ngemplak Simongan can also be categorized as "Moderate Muslim" because they still uphold the values of locality in religion. Based on the results of this study, it shows that Jam'iyyah NU, Ngemplak Simongan Village can be used as a miniature of NU moderation in suburban villages of Semarang City. Jam'iyyah NU, Ngemplak Simongan sub-district, which in fact is a sub-district in the metropolitan city of Semarang, Central Java, they often and routinely carry out Ahlussunnah wal Jama'ah An-Nahdliyyah (Aswaja NU) activities to maintain the spiritual spirit of rural Muslim communities. They also claim to be followers of the NU organization and adhere to its teachings, namely Aswaja. The Aswaja NU teachings that have been routinely carried out by Jam'iyyah NU, Ngemplak Simongan Village are quite strategic in carrying out the role of deradicalisation. They are also still consistent in maintaining their spiritual spirit through habituation of daily worship in accordance with Aswaja's teachings.

\section{REFERENCES}

As'ad, M. (2014). Pembaruan Pendidikan Islam Nahdlatul Ulama. Nizham, 3(02), 51-87.

Dimas Prayoga. (2017). Kebijakan Pemberdayaan Organisasi Kemasyarakatan Berdasarkan UU No.17 Tahun 2013 Tentang Organisasi Kemasyarakatan (Studi Kasus di Kota Pontianak). 17, 196.

Febrina, R. H., Mustika, B. U., \& Dedees, A. R. (2016). Nahdlatul Ulama: Bebas untuk Oportunis? Menelisik Kontestasi Politik pada Pemilihan Kepala Daerah Kabupaten Banyumas Periode 2008 dan 2013. Jurnal IImu Sosial dan IImu Politik, 18(2), 99. https://doi.org/10.22146/jsp.13131.

Fithriyyah, M. U., \& Umam, M. S. (2018). Quo Vadis Ormas Islam Moderat Indonesia? Meneropong Peran NU-Muhammadiyah di Era Revolusi Industri 4.0. Politea, 1(1), 15. https://doi.org/10.21043/politea.v1i1.4310.

Fuad, A. J. (2020). Akar Sejarah Moderasi Islam pada Nahdlatul Ulama. Tribakti: Jurnal Pemikiran Keis/aman, 31(1), 153-168. https://doi.org/10.33367/tribakti.v31i1.991.

Hidayah, N. (2015). Redefinisi Ontologi Aswaja dalam Pendidikan Ma'Arif di Era Kontemporer. Edukasia: Jurnal Penelitian Pendidikan Islam, 10(1), 105-124. https://doi.org/10.21043/edukasia.v10i1.787.

Hilmy, M. (2012). Quo-Vadis Islam Moderat Indonesia? Menimbang Kembali Modernisme Nahdlatul

Ulama dan Muhammadiyah. MIQOT: Jurnal Ilmu-IImu Keislaman, 36(2), 262-281. https://doi.org/10.30821/miqot.v36i2.127.

L. Man, Y. (2018). Urgensi Nahdlatul Ulama dalam Pemerintahan Indonesia. Al Imarah: Jurnal Pemerintahan dan Politik Islam, 3(2), 142. https://doi.org/10.29300/imr.v3i2.2148.

Lukman Hakim, M., \& Ali Aziz, M. (2020). Dakwah Da'i Nahdlatul Ulama dalam Mencegah Penyebaran Covid-19. Anida (Aktualisasi Nuansa Ilmu Dakwah), 20(2), 200-220. https://doi.org/10.15575/anida.v20i2.10820FakultasDakwahdanKomunikasi,UINSunanGunung DjatiBandunghttps://journal.uinsgd.ac.id/index.php/anida.

Luthfi, K. M. (2016). Islam Nusantara: Relasi Islam dan Budaya Lokal. SHAHIH : Journal of Islamicate Multidisciplinary, 1(1), 1. https://doi.org/10.22515/shahih.v1i1.53.

Mahatma, M. (2017). Paradigma Politik Nahdlatul Ulama (NU) dalam Bernegara. Mawa'lzh: Jurnal Dakwah dan Pengembangan Sosial Kemanusiaan, 8(1), 31-54. 
https://doi.org/10.32923/maw.v8i1.695.

Mubin, F. (2020). Sejarah dan Kiprah Nahdlatul Ulama di Indonesia. 3(1), 1-15. https://doi.org/10.31219/osf.io/69wjh.

Munawir, M. (2016). Aswaja NU Center dan Perannya sebagai Benteng Aqidah. SHAHIH : Journal of Islamicate Multidisciplinary, 1(1), 61. https://doi.org/10.22515/shahih.v1i1.59.

Mussardo, G. (2019). Moderasi Islam Nusantara (Studi Konsep dan Metodologi). Duta Media, 53(9), viii+98.

Naim, N. (2015). Pengembangan Pendidikan Aswaja Sebagai Strategi Deradikalisasi. Walisongo: Jurnal Penelitian Sosial Keagamaan, 23(1). https://doi.org/10.21580/ws.2015.23.1.222.

Prasetiawati, E. (2017). Menanamkan Islam Moderat Upaya Menanggulangi Radikalisme di Indonesia. Fikri, 2, No. 2,(1).

Qomar, M. (2014). Implementasi Aswaja dalam Perspektif NU di Tengah Kehidupan Masyarakat. Kontemplasi: Jurnal Ilmu-IImu Ushuluddin, 2(01). https://doi.org/10.21274/kontem.2014.2.01.

Rahim, O. A. (n.d.). Nahdlatul Ulama (Peranan dan Sistem Pendidikannya) Oleh: Ali Rahim (Dosen STAI DDI Pinrang). XIV, 174-185.

Rohmah, U. (2016). Interaksi Sosial Warga NU dan Muhammadiyah; Studi Kasus di Desa Punduhsari. Journal Of Government (Kajian Manajemen Pemerintahan dan Otonomi Daerah), 1(2).

Ryan, J. (2020). Pengaruh Dominasi Kelompok Santri dalam Dinamika Pemerintahan Desa (Studi Kasus di Desa Wringinrejo Kabupaten Mojokerto). Sawala: Jurnal Pengabdian Masyarakat Pembangunan Sosial, Desa dan Masyarakat, 1(2), 91. https://doi.org/10.24198/sawala.v1i2.27520.

Salamuddin, S. (2019). Meneguhkan Islam Nusantara: Nahdlatul Ulama dan Falsafah Pendidikan Pesantren Musthafawiyah. Journal of Contemporary Islam and Muslim Societies, 3(1), 36. https://doi.org/10.30821/jcims.v3i1.2001.

Saragih, A. (2016). Kontribusi al Jam 'iyatul Washliyah terhadap Kemerdekaan Indonesia. XL(1), 142-161.

Siregar, S., \& Suhendra, D. (2020). Harmonisasi Beribadah Warga Muhammadiyah dan Nahdlatul Ulama di Mesjid At-Tawwabin Kelurahan Tobat Kota Padangsidimpuan. Aristo, 9(1), 13. https://doi.org/10.24269/ars.v9i1.1979.

Surur, A. M., \& Munir, M. S. (2018). Dampak Ahlusunnah Wal Jamaah Terhadap Masyarakat Desa Ngreco Kecamatan Kandat Kabupaten Kediri. Spiritualita, 2(2). https://doi.org/10.30762/.v2i2.1026.

Wahyudin, D. (2017). Pendidikan Aswaja Sebagai Upaya Menangkal Radikalisme. Dinamika Penelitian: Media Komunikasi Penelitian Sosial Keagamaan, 17(2).

Yunus, B. M. (2019). Konsep Aswaja. Bandung. 